\title{
A report on the Butterflies in J hansi (U.P.) India
}

\author{
A shok K umar \\ Department of Zoology, BSNV PG College, Lucknow, (U.P.), INDIA \\ E-mail: ashokhpl@yahoo.com
}

\begin{abstract}
The city Jhansi is famous for the fort, gardens and surrounding hilly areas. These gardens and hilly areas have supported for butterflies and other insects. The butterflies are essential part of any natural ecosystem as their adults performs pollination. They are highly mobile organism and are able to maintain connectivity between the fragmental habitats. The larval stages are herbivorous and cause economic damage but adult are beneficial as pollinators of several trees and herbaceous flora. They are vulnerable to changes in flower supply resulting from deforestation and environmental pollution hence they are the biological indicators of pollution. The present study was conducted regarding the different selected sites visited by butterflies, their foraging activity and abundance at different sites of Jhansi. During the visit some species of butterflies were collected as flower visitors on different species of flowering plants (garden, cultivated, semi wild and wild) in selected areas. The species of collected butterflies were showed the most common and highly active species throughout the day. Some species namely Pieris canidia indica, Ixias mrianne (Cramer), Catopsilia crocale (Cramer), Catopsilia pyranthe (Linn.), Eurema hecabe fimbriata (Wallace) Colias electo fieldi and Colias erate (Esper) were observed mostly on the flowering plants of each site during the study. The nymphalids were found to be very common in the plane areas of Jhansi as flower visitors and only one species Papilio demoleus could be collected from only two sites.
\end{abstract}

Keywords: Biological indicator, Butterfly, Flower visitors, Natural ecosystem, Pollination

\section{INTRODUCTION}

Lepidoptera are beneficial as pollinators, silk producers, indicators of environmental quality and are appreciated for aesthetic value. Butterflies and moths (order Lepidoptera) offer good opportunities for studies on population and community ecology (Pollard, 1991). Many species are strictly seasonal, preferring only a particular set of habitats in spite of this, butterflies have been generally neglected by community ecologists and there are very few studies available on their community structure, population dynamics and the ecoclimatic factors which affect them. Butterflies, widely appreciated for their aesthetic value are important as ecological indicators (Chakravarthy et al., 1997) and flagship taxa in biodiversity inventories (Lawton et al., 1998).

Butterflies are among the most easily recognizable of all animals. They are instantly familiar and also universally popular. Their wings, unlike those of most other insects, are colorful, opaque and are of characteristic shape. The development of color the range, diversity, brilliance and kaleidoscopic assortment of patterns exhibited by butterflies is unrivalled anywhere in the animal's kingdom, except possibly by the birds. Butterflies are typically active during the day and because they are so skilled in flight they have achieved an almost world-wide distribution, though as with most animals groups. There is a greater diversity to be found in the tropics unfortunately, butterflies are threatened by habitat destruction and fragmentation almost everywhere (Mathew, 2001). Many butterflies occupy vast ranges, covering parts of Europe, Africa, Asia and Australia. As part of their adaptation to survive in the varied environments they inhabit, one often finds that the same butterfly species looks quite in different parts of its range. Such different forms, called geographical variations or subspecies, are usually named to facilitate reference to them. Butterflies have been studied systematically since the early $18^{\text {th }}$ century and 19,238 species had been documented worldwide (Heppner, 1998). This figure is not constant because of the continuous discovery of new butterflies (Lewis, 1973; Stokoe, 1974; Mani, 1986; Goodden, 1997; Green and Huang, 1998; Barua et al., 2004; Ambrose and Raj, 2005; Alphonsa, 2006; Chandra et al., 2007; Parag and Omkar 2009) and also due to ongoing disagreements between taxonomists over the status of many species. The distribution of butterflies involves both expanding and contracting ranges, but natural changes in the distribution of species can be difficult to deduce because they tend to be slower and subtler than the dramatic changes caused by man. Unfortunately, most expanding ranges involve introduced species and most contracting ranges are due to the destruction of natural habitats (Lafontaine, 1997). Expansion in a species range may often be in response 
to human activities favoring these species, making these butterflies opportunists. In order to document such temporal changes over time, a baseline faunal inventory must first be established.

It is essential that we document the butterfly fauna of certain regions so that steps may be taken to ensure the survival of these fascinating creatures for future generations. There is little that can be done to save our butterflies once their habitats are destroyed. Thus, it is important to environment and avoids further damaging the already fragile balance of nature (Whalley, 1988, 1992; Verma, 2009). Even though butterflies are the one of the most admired insects groups be humans, is not well known that they are sensitive to climate and chemical changes. It's important to test the variation in butterfly family and habitats dynamics to establish diversity patterns (Gilbert and Singer, 1975).

The present study was started with a view to examine the butterfly population across different habitats. With quantitative data on butterfly populations gathered from a variety of habitats, this study did attempt, perhaps for the first time in Jhansi.

\section{MATERIALS AND METHODS}

During work, four sites were selected for extensive sampling to determine the butterflies in Jhansi. These sites were selected on the basis of their position in vegetation and accessibility.

The Jhansi Fort played a major role during the first war of Indian Independence, built by Raja Vir Singh Judeo in 1613. The Fort is an architectural delight to eyes, due to its size and beauty. The fort was made at the strategically location, to be in the centre of the state. More flowering and vegetation in Jhansi Fort.

University campus has many gardens and parks, different type of butterflies seen in these parks and gardens. Then there is the state vegetables and flowers exhibition that are worth visiting while in Jhansi. Different types of vegetables, fruits and flowers.

Parichha dam, the Geographical position of this site is at east side of Jhansi .This dam is built over Betva River. The site shows varying form of flowing garden and big water body.

Side of Jhansi Gwalior Highway on south side of Jhansi, along the side of national highway ornamental vegetation was one of the sites for the study. This site extends up to $2 \mathrm{~km}$ and was rich in ornamental and wild plants providing site for butterflies nectaring and egg laying.

Butterflies were collected by means of netting within one kilometer diameter at each sampler site from September 2009-August 2010. Each site was sampled between 8-12 AM per visit at interval of 2 or 3 days throughout the study period. Butterflies were caught using an aerial net, then transferred to killing jar, using a liquid fumigant or killing agent (ethyl acetate) that produced a toxic atmosphere that the butterfly cannot breath. The captured butterflies were brought to the laboratory and their wings were spread on the spreading board, further these butterflies were stored in insect box by pinning them. Later the dried specimens were kept in an insect box for future reference. Butterflies were identified based on standard monographs of (Wynter-Blyth, 1957), (Kunte 1996, 1997 and 2000).

\section{RESULTS AND DISCUSSION}

Six hundred and thirty seven butterflies collected from all study sites, which include 27 identified species belonging in five families (Table 1 and 2). Nymphalidae family was the most common followed by Pieridae, Lycaenidae, Papilionidae, followed by Riodinidae family and total study was family and sitewise.

In Nymphalidae family, there were eleven species, A tella phalanta, Precis lemonias, Precis orithya, Precis hierta, Tirumala limniace, Hypolimnas missipus, Danaus genutia, D anaus chrysippus, Euploea core, Ariadne merione, M elanitis leda.

In Pieridae family, there were eight species, Ixias marianne, Catopsilia pyranthe, E urema brigitta, Pieris rapae, Catopsilia crocale, Anaphaeis aurota, Cepora nerissa, Colotis fausta.

In Lycaenidae family five species, Chilades contracta, Zizina otis, Catochrysops strabo, Lampides boeticus, Tarucus extricatus were observed.

In Papilionidae family two species, Papilio demoleus, Atrophaneura aristolochiae were observed.

Only one species Abisara echerius under family Riodinidae was observed. 27 species of different 5 families are recorded from all study sites (Table 1 and 2).

In University Campus, 182 butterflies were collected under 25 species - A. phalanta (4), P. lemonias (1), P. orithya (2), P. hierta (2), T. limniace (3), H. missipus (2), D. genutia (5), D. chrysippus (11), E. core (3), A. merione (1), I. marianne (31), C. pyranthe (1), E. brigitta (72), P. rapae (1), C. crocale (6), A. aurota (13), C. nerissa (5), C. fausta (1), C. contracta (6), Z. otis (3), C. strabo (2), L. boeticus (1), T. extricatus (3), P. demoleus (2), A. aristolochiae (1). In Parichha dam 125 butterflies collected under 22 species, A. phalanta (1), P. orithya (4), P. hierta (1), T. limniace (3), H. missipus (1), D . genutia (2), D. chrysippus (4), E. core (6), M. leda (1), I. marianne (17), C. pyranthe (4), E. brigitta (59), C. crocale (1), A. aurota (3), C. nerissa (6), C. fausta (3), C. contracta (2), C. Strabo (1), L. boeticus (2), P. demoleus (1), A. aristolochiae (2), A. echerius (1). In Side of Jhansi Gwalior Highway 145 butterflies under 21 species recorded, these are A. phalanta (3), P. lemonias (8), P. orithya (1), T. limniace (2), D. genutia (4), D. chrysippus (6), E. core (21), A. merione (2), M. leda (3), I. marianne (27), C. pyranthe (3), E. brigitta (37), P. rapae 
Table 1. Taxonomic composition and number of individuals of butterflies recorded from different study sites in Jhansi.

\begin{tabular}{|c|c|c|c|c|c|c|c|}
\hline $\begin{array}{l}\text { S. } \\
\text { No. }\end{array}$ & Species/F amily & Common name & U.C. & P.D. & S.J.G.H. & J.F. & Remarks \\
\hline & Family: Nymphalidae & & & & & & \\
\hline 1 & Atella phalanta & Common leopard & 4 & 1 & 3 & - & $\mathrm{R}$ \\
\hline 2 & Precis lemonias & Lemon pansy & 1 & - & 8 & 2 & $\mathrm{R}$ \\
\hline 3 & Precis orithya & Blue pansy & 2 & 4 & 1 & 10 & $\mathrm{C}$ \\
\hline 4 & Precis hierta & Yellow pansy & 2 & 1 & - & 1 & $\mathrm{R}$ \\
\hline 5 & Tirumala limniace & Blue tiger & 3 & 3 & 2 & 6 & $\mathrm{C}$ \\
\hline 6 & Hypolimnas missipus & Danaid eggfly & 2 & 1 & - & 2 & $\mathrm{R}$ \\
\hline 7 & Danaus genutia & Striped tiger & 5 & 2 & 4 & 7 & $\mathrm{C}$ \\
\hline 8 & Danaus chrysippus & Plain tiger & 11 & 4 & 6 & 2 & $\mathrm{C}$ \\
\hline 9 & Euploea core & Common crow & 3 & 6 & 21 & 8 & $\mathrm{C}$ \\
\hline 10 & Ariadne merione & Common castor & 1 & - & 2 & 1 & V.R. \\
\hline 11 & $\begin{array}{l}\text { M elanitis leda } \\
\text { Family: Pieridae }\end{array}$ & Common evening brown & - & 1 & 3 & 2 & V.R. \\
\hline 12 & Ixias marianne & White orange tip & 31 & 17 & 27 & 32 & M.C. \\
\hline 13 & Catopsilia pyranthe & Mottled emigrant & 1 & 4 & 3 & 2 & $\mathrm{C}$ \\
\hline 14 & Eurema brigitta & Small grass yellow & 72 & 59 & 37 & 68 & M.C. \\
\hline 15 & Pieris rapae & Small white & 1 & - & 2 & 1 & $\mathrm{R}$ \\
\hline 16 & Catopslia crocale & Common emigrant & 6 & 1 & 3 & 4 & $\mathrm{C}$ \\
\hline 17 & Anaphaeis aurota & Pioneer & 13 & 3 & 1 & 3 & $\mathrm{C}$ \\
\hline 18 & Cepora nerissa & Common gull & 5 & 6 & 10 & 7 & $\mathrm{C}$ \\
\hline 19 & $\begin{array}{l}\text { Colotis fausta } \\
\text { Family: L ycaenidae }\end{array}$ & Large salmon arab & 1 & 3 & 1 & 1 & $\mathrm{C}$ \\
\hline 20 & Chilades contracta & Small cupid & 6 & 2 & 2 & 3 & $\mathrm{C}$ \\
\hline 21 & Zizina otis & Lesser grass blue & 3 & - & 2 & 6 & $\mathrm{R}$ \\
\hline 22 & Catochrysops strabo & Forget me not & 2 & 1 & - & 4 & $\mathrm{R}$ \\
\hline 23 & Lampides boeticus & Pea blue & 1 & 2 & - & 7 & $\mathrm{R}$ \\
\hline 24 & $\begin{array}{l}\text { Tarucus extricatus } \\
\text { Family: Papilionidae }\end{array}$ & Rounded pierrot & 3 & - & 1 & 2 & $\mathrm{R}$ \\
\hline 25 & Papilio demoleus & Lime butterfly & 2 & 1 & 5 & 3 & $\mathrm{C}$ \\
\hline 26 & $\begin{array}{l}\text { Atrophaneura aristolochiae } \\
\text { Family: Riodinidae }\end{array}$ & Common rose & 1 & 2 & - & - & V.R. \\
\hline 27 & Abisara echerius & Plum judy & - & 1 & - & 2 & V.R. \\
\hline
\end{tabular}

.U.C.- University Campus, *R - Rare, ·P.D - Parichha dam, *C - Common, -S.J.G.H.- Side of Jhansi Gwalior Highway, *M.C.Most common, J.F.- Jhansi Fort, * V.R.-Very rare

(2), C. crocale (3), A. aurota (1), C. nerissa (10), C. fausta (1), C. contracta (2), Z. otis (2), T. extricatus (1), P. demoleus (5), A. aristolochiae (1).

In Jhansi Fort 186 butterflies of 25 species recorded, these are P. lemonias (2), P. orithya (10), P. hierta (1), T. limniace (6), H . missipus (2), D . genutia (7), D. chrysippus (2), E. core (8), A. merione (1), M. leda (2), I marianne (32), C. pyranthe (2), E. brigitta (68), P.rapae (1), C. crocale (4), A. aurota (3), C. nerissa (7), C. fausta (1), C. contracta (3), Z. otis (6), C. strabo (4), L. boeticus (7), T. extricatus (2), P. demoleus (3), A. echerius (2).

The commonly seen butterflies in the all selected sites were Small grass yellow (E. brigitta ), White orange tip (Ixias M arianne), Blue pansy (P. orithya), Blue tiger ( $T$. limniance), Striped tiger (D. genutia), Plain tiger (D. chrysippus), Common crow (E. core), Mottled emigrant (C. Pyranthe), Common emigrant (C. crocale), Pioneer (A. aurota), Common gull (C. nerissa), Large salmon arab (C. fausta), Small cupid (C. contracta), Lime butterfly ( $P$. demileus), but the most abundant species was $\mathrm{E}$. brigitta
(Pieridae), with 236 individuals. I. M arianne (Pieridae), the next most abundant species with 107 individuals in all collected species. E. brigitta, I. Marianne are most common butterflies in Jhansi. P. orithya, T. Iimniace, D. genutia, D. chrysippus, E. core, C. pyranthe, C. crocale, $A$. aurota, $C$. nerissa, $C$. fausta, $C$. contracta, $A$. demoleus are common butterflies. A. phalanta,P. lemonias, P. hierta, H. missipus, P. rapae, Z. otis, C. Strabo, L. boeticus, T. extricatus are rare butterflies. A. aristolochiae, A. echerius, $A$. merione, $M$. leda are very rare butterflies (Table 1).

The abundance and diversity of butterflies of the in and around Jhansi could be attributed to the evergreen forest of study sites at low altitude that receives fairly good rainfall and experience only a brief period of dryness. The diversity and abundance of butterflies were found poor where human activities such as habitat fragmentation and destruction, grazing, monoculture, forest fire etc., have been taking place. Hence, prevention of habitat fragmentation and destruction, regulation of 
Table 2. List of number of individuals and number of species in different family.

\begin{tabular}{llcc}
\hline $\begin{array}{l}\text { S. } \\
\text { No. }\end{array}$ & Family & $\begin{array}{c}\text { Number of } \\
\text { individuals }\end{array}$ & $\begin{array}{c}\text { No. of } \\
\text { species }\end{array}$ \\
\hline 1 & Nymphalidae & 148 & 11 \\
2 & Pieridae & 425 & 8 \\
3 & Lycaenidae & 47 & 5 \\
4 & Papilionidae & 14 & 2 \\
5 & Riodinidae & 3 & 1 \\
\hline & Total & 637 & 27 \\
\hline
\end{tabular}

grazing, avoidance of monoculture and prevention of forest fire etc., in Jhansi and general awareness programme to people especially to those who visited historical, picnic place and university viz., Jhansi fort, Parichha dam and Bundelkhand University inside the study sites forest will conserve and augment the butterfly fauna of Jhansi. Further studies on the biodiversity of butterflies with special reference to their host plants and factors that affect their distribution, diversity and abundance will be rewarding experience.

The study sites had various habitats ranging from natural forest to gardens and plantation. The butterfly diversity was also varied in these habitats but the pattern of variation was different. Present study revealed that although at undisturbed and wild sites there was less species richness, they were the excellent sites for the occurrence of unique species, were as in disturbed habitats and human impacted sites species richness was increased but the uniqueness was less. These observations are in good agreement with Padhey et al., 2006, Kunte, 2001, Tiple et al., 2007 and Kumar, 2011 stating that impact zones are richer in species richness. When comparison was made at different sites under investigation, highest number of species were recorded from Jhansi fort and University campus (25 and 25) while least number of species 22 and 21 from Parichha Dam and sides of Jhansi-Gwalior highway.

Ealier studies on butterfly species diversity of some cities in India indicactes that comparatively Jhansi city has poorest butterfly diversity (27Sps.) than cities like Pune 103 Sps. (Kunte, 1997); metropolitian Delhi 86 Sps. (Larsen, 2002); Visakapatnam 68 Sps. (Solmanraju, 2004) and Amravati 52 Sps. (Tiple et al., 2006). The butterfly fauna of Nagpur city of certral India is very rich and very intersing with 145 Sps. (Tiple, 2009); members of nymphalidae, pieridae, lycaenidae and papilionidae reported in Jhansi were also reported in Nagpur city.

\section{REFERENCES}

Ambrose P. Dunston and Raj, D. Senthil (2005). Butterflies of kalakad- mundanthurai tiger reserve, Tamilnadu. Zoos'Print J ournal, 20 (12): 2100-2107.

Alphonsa Xavier. (2006). Butterfly fauna of Government arts
\& Science College campus, Kozhikode, Kerala. Zoos' P rint J ournal, 21 (3): 2263-2264.

Barua, K.K., Kakati D. and Kalita J. (2004). Present Status of Swallowtail butterflies in Garbhanga reserve forest, Assam, India. Zoos' Print J ournal,19 (4):1439-1441.

Chakravarthy, A. K., Rajagopal, D. and R. Jaganntha. (1997). Insect as bio indicators of conservation in the tropics. Zoos' Print J ournal. 12:21-25

Chandra, K., Sharma R.M., Ajit Singh and Singh R.K. (2007). A checklist of butterflies of Madhya Pradesh and Chhattisgarh States, India. Zoos' Print J ournal, 22 (8):27902798.

Gilbert, L.E. and Singer, M.C. (1975). Butterflies Ecology. Unknown 4098: 365-397

Godden, R. (1997).The Wonderful World of Butterflies and Moths. Hamlyn Pub. Group Ltd., London: 96

Green, J. and Huang, A. (1998). Butterflies of South Vancouver Island. Co-op resort. Royal British Columbia Museum. Available online at: http://rbcm.gov.bc.ca/nh- papers/anneh/ text/coverpage.html

Heppner, J. (1998). Classification of Lepidoptera.Part1 Introduction. Holarctic.Lep.Vol.5, Supplement 1:148

Kunte, K.J. (1996). Strange Behaviour of Mottled Emigrant male. J ournal Bombay Natural H istory Society, 3(2): 307308

Kunte, K. J. (1997). Seasonal Patterns in the Butterfly Abundance and Species Diversity in Four Tropical Habitats in Northern Western Ghats. J . Biosci., 22 (5): 593-603

Kunte, K.J. (2000). India a Lifescape Butterflies of Peninsular India. Universities Press (India) Limited.

Kunte, K.J. (2001). Butterfly diversity of Pune city along the human impact gradient. J .Ecol. Soc., 13/14: 40-45.

Kumar, A. (2011). A study on butterfly abundance and diversity in Jhansi, Uttar Pradesh, India. The biosphere, 3(1): 45-48.

Larsen, T.B. (2002). The butterflies of Nilgiri mountain of southern India (Lepidoptera: Rhopalocera). J ournal of B ombay Natural history Society, 85 (1): 30-43.

Lafontaine, J.D. (1997). Butterflies and Moths. In Smith, I.M. (ed.).Assessment of Species Diversity in the Mixedwood Pains Ecozone. Printed Summary [1997]. Eman Publication: $31+$ CDROM

Lawton, J.H., D.E. Bignell, B. Bolton, G.F. Bloemers, P. Eggleton, P.M. Hemmond, M.Hodda, R.D. Holts, T.B. Larsen, N.A. Mawdsley, N.E. Stork, D.S. Srivastava and A.D. Watt. (1998). Biodiversity Inventories Indicator Taxa and Effect of Habitat Modification in Tropical Forest. Nature, 391:72-76

Lewis, H.I. (1973). Butterflies of the world. Harrap. London. Mani, M.S. (1986). Butterflies of Himalaya. New Delhi, India .Oxford IBH Publishing Co.

Mathew, G. (2001). Conservation of Invertebrates through Captive Breeding: A Study With Reference to Butterflies. KFRI Research Report No.220: 210

Pollard, E.(1991). Monitoring Butterfly Numbers in Monitoring for Conservation and Ecology (ed.). F.B. Goldsmith (London: Chapman and Hall):87

Padhey, A.D., Dahanukar, M., Paigankar, M., Deshpande, M. and Deshpande, D. (2006). Season and landscape wise distribution of butterflies in Tamhini, Northern western Ghats India, Zoos Print J ., 21:2175-2181. 
Parag, E. and Omkar, D. (2009). Three additions to the known butterfly (Lepidotera: Rhopalocera and Grypocera) fauna of Goa, India. J ournal of Threatened Taxa, 1(5): 298-299. Solmanraju, A. J.(2004). Nector host plants of some butterflies species at Visakapatnam. Sci. and Cul., 70: 187-190.

Stokoe, W. J. (1974). The Observer's Book of Butterflies.W.J. Frederick Warne and Co., London: 191

Tiple, A.D., Khurad, A.M. and Dennis R.L.H. (2007). Butterfly diversity in relation to a human impact gradient on Indian university campus. Nota Lepid., 30(1);179-188.

Tiple, A.D., Deshmukh,V. P. and Dennis R.L.H. (2006). Factors influencing nector plants resource visit by butterfly on a university campus: implication for conservation. Nota Lepid., $28: 213-224$
Tiple, A..D. (2009). Butterflies from Nagpur city, central India: Diversity, Population, nector and larval plants and the implications for conservation, PhD Thesis, RTM Nagpur University Nagpur India 1-146.

Verma, S.K. (2009). Species Composition and Seasonal variation of butterflies in Dalma Wildlife Sanctury. Jharkhand, India.J ournal of Threatened Taxa, 1 (5): 295-297.

Whalley, P. (1988). Butterflies and Moths. In association with the natural history museum, Dorling Kindersley limited, London.

Whalley, P. (1992). Eyewitness Guide of Butterflies and Moths. Dorling Kindersley. London: 63

Wynter-Blyth, M.A. (1957). Butterflies of the Indian Region. Bombay $\mathrm{N}$ atural H istory Society, CME Press Poona. 